\title{
Growth and fluorescence rates of Mesosphaerum suaveolens (L.) Kuntze under saline stress and salicylic acid doses
}

\author{
Jackson Silva Nóbrega ${ }^{1} \oplus$, Riselane de Lucena Alcantâra Bruno ${ }^{1} \oplus$, Francisco Romário Andrade Figueiredo ${ }^{2} \oplus$, \\ Toshik larley da Silva ${ }^{3}{ }^{\circ}$, Reynaldo Teodoro de Fátima ${ }^{1}{ }^{\circ}$, Jean Telvio Andrade Ferreira ${ }^{1}{ }^{\circ}$, \\ Ronimeire Torres da Silva ${ }^{1}$, Lourival Ferreira Cavalcante ${ }^{1}[0$

\footnotetext{
1 Universidade Federal da Paraíba, Centro de Ciências Agrárias, Programa de Pós-Graduação em Agronomia, Areia, PB, Brasil. E-mail: jacksonnobrega@hotmail.com; lanebruno.bruno@gmail.com; reynaldo.t16@gmail.com; jeantelvioagronomo@gmail.com; ronimeiretorres@hotmail.com; lofeca1946@yahoo.com.br

${ }^{2}$ Universidade Federal Rural do Semi-Árido, Programa de Pós-Graduação em Fitotecnia, Mossoró, RN, Brasil. E-mail: romarioagroecologia@yahoo.com.br

${ }^{3}$ Universidade Federal de Viçosa, Programa de Pós-Graduação em Fitotecnia, Viçosa, MG, Brasil. E-mail: iarley.toshik@gmail.com
}

ABSTRACT: Mesosphaerum suaveolens (L.) Kuntze is a species of high phytotherapeutic and aromatic potential and quite widespread in Northeastern Brazil. However, the scarcity of good quality water and the high content of salts contained in the soil and irrigation water of the semi-arid region can compromise the crop growth and yield. Therefore, this study aimed to evaluate the effect of seed treatment with salicylic acid on the growth rates and the fluorescence indexes of chlorophyll ' $a$ ' from M. suaveolens plants irrigated with saline waters. The experiment was conducted in a randomized complete block design with a $5 \times 5$ incomplete factorial design, with five electrical conductivities of the irrigation water $\left(E C w=0.5,1.45,5.00,8.55\right.$ and $\left.10.0 \mathrm{dS} \mathrm{m}^{-1}\right)$ and five salicylic acid doses $\left(S A=0.0,0.29,1.0,1.71\right.$ and $\left.2.0 \mathrm{mM} \mathrm{L}^{-1}\right)$, generated by the Box Central Compound matrix. The evaluated variables were the absolute and relative growth rates for stem height and diameter and the indexes of fluorescence and quantum yield of photosystem II. The salinity of the water reduces the growth and the fluorescence indexes of the plants. The seeds treatment with salicylic acid at the doses of 1.99 and $0.69 \mathrm{mM} \mathrm{L}^{-1}$ attenuates the damaging effect from saline stress on the absolute and relative growths for the stem diameter.

Key words: growth reducer; medicinal species; salinity; seed treatment

\section{Taxas de crescimento e fluorescência de Mesosphaerum suaveolens (L.) Kuntze sob estresse salino e doses de ácido salicílico}

RESUMO: A Mesosphaerum suaveolens (L.) Kuntze é uma espécie de elevado potencial fitoterápico e aromático e bastante difundida no Nordeste brasileiro. Porém, o elevado teor de sais contidos no solo e na água de irrigação da região semiárida podem comprometer o crescimento e produtividade da cultura. Assim, objetivou-se avaliar o efeito do tratamento de sementes com ácido salicílico nas taxas de crescimento e índices de fluorescências da clorofila 'a' de plantas de alfazema irrigadas com águas salinas. 0 experimento foi conduzido em delineamento de blocos casualizados, em esquema fatorial incompleto $5 \times 5$, com cinco níveis condutividade elétrica da água de irrigação (CEa= 0,$5 ; 1,45 ; 5,00 ; 8,55$ e $\left.10,0 \mathrm{dS} \mathrm{m}^{-1}\right)$ e cinco doses de ácido salićlico (AS= 0,0; 0,29; 1,0; 1,71 e 2,0 $\mathrm{mM} \mathrm{L}^{-1}$ ), geradas pela matriz Composto Central de Box. Foram avaliadas as variáveis de taxas de crescimento absoluto e relativo para a altura e diâmetro do caule e os índices de fluorescência e 0 rendimento quântico do fotossistema II. A salinidade da água reduz o crescimento e os índices de fluorescência das plantas. 0 tratamento das sementes de ácido salicílico nas doses de 1,99 e $0,69 \mathrm{mM} \mathrm{L}^{-1}$ atenua o efeito danoso do estresse salino sobre o crescimento absoluto e relativo para o diâmetro do caule.

Palavras-chave: regulador de crescimento; espécie medicinal; salinidade; tratamento de sementes 


\section{Introduction}

The Mesosphaerum suaveolens (L.) Kuntze, part of the Lamiaceae family, has herbal and aromatic properties used in traditional medicine. This crop is considered as a multipurpose species due to its biological properties and antifungal, insecticidal and anti-inflammatory actions (Figueirêdo et al., 2018). The main utility of this plant is the production of an essential oil rich in phytotherapeutic compounds, however, its growth and production of biomass and oil vary according to the cultivation conditions (Arruda et al., 2018).

Since the $M$. suaveolens is a species that demonstrates favorable conditions in adapting to the Brazilian Northeastern semi-arid and for its use in the popular medicinal of the region, the crop shows potential to be explored. However, the Northeast region is characterized by containing high salt content in both the soil and the waters used in irrigation, with compromising reflexes on the crops productive capacity. The high salt content sometimes is not that high; however, when above the level tolerated by the crop, it causes growth inhibition and interferes negatively in the plant physiology and biomass formation (Bezerra et al., 2018).

As according to Silva et al. (2013), salinity harms plants in two forms overall, by reducing the soil osmotic potential, with increased saline content resulting in greater energy expenditure in absorbing water and nutrients; and by the phytotoxicity of specific ions such as sodium, boron, bicarbonates and chloride, which disturbs the physiological and biochemical processes.

In plants under stress conditions, such as the saline case, the fluorescence indexes of chlorophyll ' $a$ ' are important in estimating the damage caused to the photosynthesis. This is because they allow evaluating the physiological condition of the photosystem II and the electron transport chain, as well as the damage caused by salt stress on the photosynthetic apparatus (Kalaji et al., 2016).

Due to serious problems regarding soil salinity or irrigation water, researchers in the area are striving for techniques that minimize or reduce the damage from salt stress on the plant growth. Among these, the use of phytohormones stands out, acting on the plant growth regulation; such as the case of the salicylic acid, for example, a phenolic compound that function by regulating several physiological processes, considered as a signaling molecule that generally operates in the defense mechanisms of the plant under stress, (Taiz et al., 2017); including in the salinity (Silva et al., 2018).

The salicylic acid mediates the action of proteins and enzymes involved in cell growth, photosynthesis and plant respiration, expression of genes that promote accumulation of reactive-oxygen species (ROS) in the apoplast of plants under salt stress (Sharma et al., 2017 Hernández-Ruiz \& Arnao, 2018).

In light of this context, the objective was to evaluate the effects of the irrigation water salinity and of the salicylic acid on the growth rates and fluorescence indexes from the chlorophyll ' $a$ ' of $M$. suaveolens plants.

\section{Materials and Methods}

The experiment was conducted in a greenhouse, part of the Department of Phytotechnics and Environmental Sciences of the Agricultural Sciences Center, Federal University of Paraíba (CCA/UFPB), Campus II, Areia - Paraíba.

The experimental design used was the randomized complete block in a $5 \times 5$ incomplete factorial design, referring to five levels of electrical conductivities of the irrigation water (ECW: 0.5; 1.45; $5.0 ; 8.55$ and $10.0 \mathrm{dS} \mathrm{m}^{-1}$ ) and five salicylic acid doses $(0.0 ; 0.29 ; 1.0 ; 1.71$ and $2.0 \mathrm{mM}$ $\left.\mathrm{L}^{-1}\right)$, with four replicates composed of two plants, generated by the experimental matrix Box Central Compound (Mateus et al., 2001).

The different electrical conductivities were obtained by adding sodium chloride $(\mathrm{NaCl})$ to the water of the supply system ( $\left.E C W=0.5 \mathrm{dS} \mathrm{m}^{-1}\right)$ in the required proportions, with the values assessment aided by portable conductivimeter of the microprocessor-style model, Instrutherm (model CD-860). Irrigations were daily, from 10 days after sowing, with the water volume applied established through drainage lysimetry, found by the difference in the amount of water applied and drained (Alves et al., 2017).

The seeds were treated with salicylic acid by diluting its doses in $200 \mathrm{~mL}$ of distilled water and soaking the seeds in this solution for a period of 8 hours inside plastic containers, kept at a mean temperature of $25.2{ }^{\circ} \mathrm{C}$ and relative humidity of around $54.2 \%$. Afterwards the imbibition period, the seeds were washed with distilled water in order to remove acid excess.

The used seeds were all obtained from native plants located in the Novo Horizonte settlement, municipality of Várzea - PB. The experiment was conducted in polyethylene bags with capacity for $1.2 \mathrm{dm}^{3}$, where 10 seeds were sown per bag, with thinning held after the emergence establishment, around 10 days after sowing, leaving only one plant per vessel.

The vessels were filled with substrate formulated from the mixture of a "Latossolo" (Oxisol) soil type, washed sand and tanned bovine manure in the 3:1:1 proportion (Embrapa, 2018), with its chemical composition displayed in Table 1.

In order to determine the growth rates, two evaluations were performed at 15 and 45 days, with their involved variables calculated as the following:

Table 1. Chemical characterization of the substrate used in the experiment.

\begin{tabular}{|c|c|c|c|c|c|c|c|c|c|c|}
\hline \multirow{2}{*}{ pH } & O.M. & $\bar{P}$ & $\overline{\mathbf{K}^{+}}$ & $\mathrm{Ca}^{+2}$ & $\mathrm{Mg}^{+2}$ & $\mathrm{Na}^{+}$ & SB & $\mathrm{H}^{+}+\mathrm{Al}^{+3}$ & $\mathrm{Al}^{+3}$ & $\overline{\text { CEC }}$ \\
\hline & $\left(\mathrm{g} \mathrm{kg}^{-1}\right)$ & \multicolumn{2}{|c|}{$\left(\mathrm{mg} \mathrm{kg}^{-3}\right)$} & \multicolumn{7}{|c|}{$\left(\mathrm{cmol}_{\mathrm{c}} \mathrm{dm}^{-3}\right)$} \\
\hline 7.8 & 22.2 & 85.5 & 693.6 & 2.9 & 1.59 & 0.23 & 6.5 & 0.0 & 0.0 & 6.5 \\
\hline
\end{tabular}

$\mathrm{O} . \mathrm{M}$. = organic matter; $\mathrm{SB}=$ saturation of bases; $\mathrm{CEC}=$ cation exchange capacity. 
- Rates of absolute and relative growth for height and diameter of the stem: established from adapting the methodology previously described by Benincasa (2003), according to the equations 1 and 2 :

$$
\mathrm{AGRHp}=\frac{(\mathrm{Ap} 2-\mathrm{Ap} 1)}{(\mathrm{t} 2-\mathrm{t} 1)} \quad \mathrm{AGRD}=\frac{(\mathrm{D} 2-\mathrm{D} 1)}{(\mathrm{t} 2-\mathrm{t} 1)}
$$

In which: AGRHp = absolute growth rate for the plant height; $A G R D=$ absolute growth rate for the stem diameter; Ap1 and $\mathrm{D} 1=$ value of the evaluation 15 days applying saline waters; Ap2 and $D 2=$ height value of the evaluation 45 days after applying saline waters; $\mathrm{t} 1$ = number of days of the first evaluation (15 days); $\mathrm{t} 2$ = number of days of the second evaluation ( 45 days).

$$
\mathrm{RGRHp}=\frac{(\ln \mathrm{Ap} 2-\ln \mathrm{Ap} 1)}{(\mathrm{t} 2-\mathrm{t} 1)} \quad \mathrm{RGRD}=\frac{(\ln \mathrm{D} 2-\ln \mathrm{D} 1)}{(\mathrm{t} 2-\mathrm{t} 1)}
$$

In which: RGRHp = relative growth rate for the plant height; $R G R D=$ relative growth rate for the stem diameter; $\ln A p 1$ and $\operatorname{lnD} 1=$ natural logarithm from the value of the evaluation 15 days after applying saline waters; $\ln A p 2$ and $\ln D 2$ = natural logarithm from the value of the evaluation 45 days after applying saline waters; $\mathrm{t} 1$ = number of days of the first evaluation (15 days); $\mathrm{t} 2$ $=$ number of days of the second evaluation ( 45 days).

The evaluation of chlorophyll fluorescence variables was with the aid of a modulated fluorometer (Sciences Inc. - Model OS-30p, Hudson, USA). Clamps for leaves were placed for 30 minutes before the reading to adapt the leaves to the dark, with the initial fluorescence $\left(F_{0}\right)$, maximum fluorescence $\left(F_{m}\right)$, variable fluorescence $\left(F_{v}=F_{m}-F_{0}\right), F_{v} / F_{0}$ ratio and the quantum yield of the photosystem II $\left(F_{v} / F_{m}\right)$.

The data were subjected to the analysis of variance by the $F$ test $(p>0.05)$ and by regression, employing the SAS University statistical program for processing data (Cody, 2015).

\section{Results and Discussion}

The interaction between the different electrical conductivities of the irrigation water and the salicylic acid doses promoted a significant effect on the rates of absolute and relative growth of the stem diameter (Table 2). ECw had a significant isolated effect on the rate of absolute and relative growth of the plant height. The salicylic acid doses influenced the absolute growth rate regarding the plant height.

The absolute growth rate of the stem showed the largest increments (0.18) in plants submitted to seed treatment at a $1.99 \mathrm{mM} \mathrm{L}^{-1}$ dose of SA and irrigated with water of $0.5 \mathrm{dS} \mathrm{m}^{-1}$ EC (Figure $1 \mathrm{~A}$ ). As for the relative growth rate, the maximum

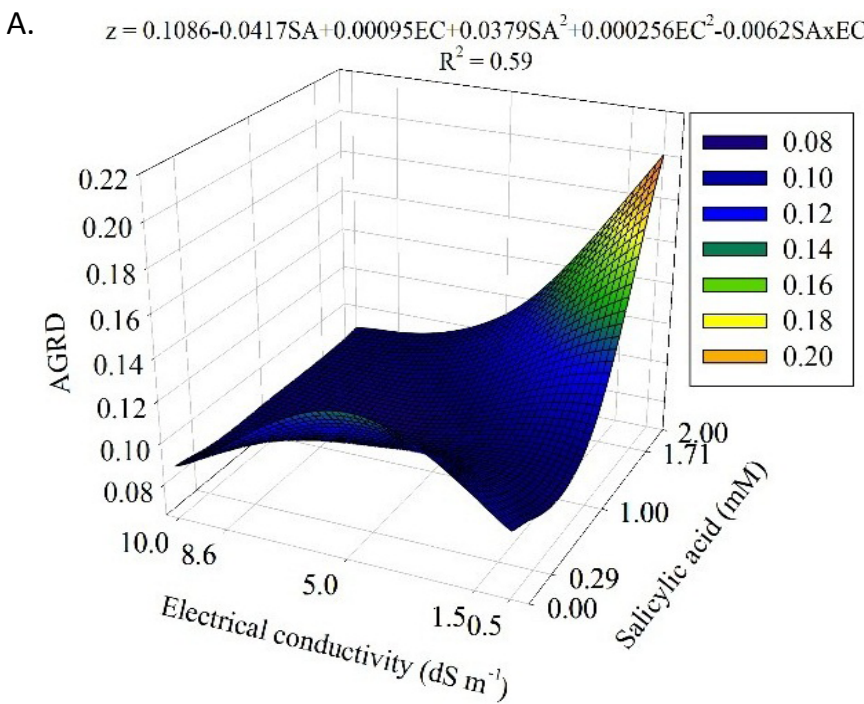

B. $\mathrm{z}=0.0380-0.0276 \mathrm{SA}+0.000483 \mathrm{EC}+0.0182 \mathrm{SA}^{2}+0.0000690 \mathrm{EC}^{2}-0.00184 \mathrm{SAxEC}$

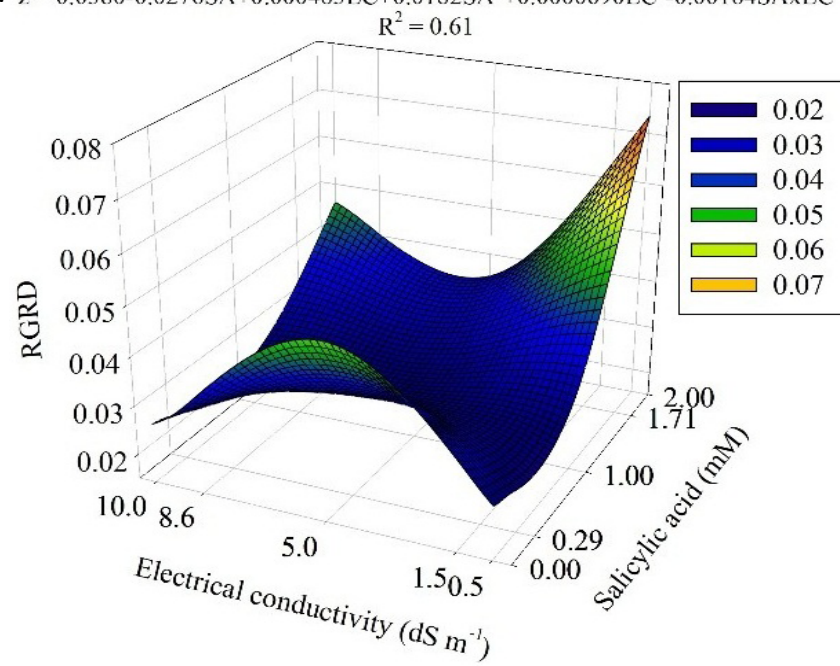

Figure 1. Absolute $(A)$ and relative $(B)$ growth rate for the stem diameter of Mesosphaerum suaveolens (L.) Kuntze plants submitted to salicylic acid doses and irrigation water salinity.

Table 2. Summary of the analysis variance of the absolute (AGRH) and relative (RGRH) growth rates for plant height, absolute (AGRD) and relative (RGRD) growth rates for stem diameter of Mesosphaerum suaveolens (L.) Kuntze plants subjected to

\begin{tabular}{|c|c|c|c|c|c|}
\hline SV & DoF & AGRH & RGRH & AGRD & RGRD \\
\hline Block & 3 & $0.01^{\mathrm{ns}}$ & $4.4970 \mathrm{E}-02^{\mathrm{ns}}$ & $7.4462 \mathrm{E}-04^{\mathrm{ns}}$ & $1.5644 \mathrm{E}-04^{\mathrm{ns}}$ \\
\hline SA & 1 & $0.14^{\mathrm{ns}}$ & $1.2289 \mathrm{E}-04^{\mathrm{ns}}$ & $7.3530 \mathrm{E}-05^{\mathrm{ns}}$ & $1.4800 \mathrm{E}-05^{\mathrm{ns}}$ \\
\hline $\mathrm{ECW}$ & 1 & $1.23^{* *}$ & $1.6822 \mathrm{E}-03^{* *}$ & $3.3043 \mathrm{E}-03^{\text {ns }}$ & $2.6239 \mathrm{E}-04^{\mathrm{ns}}$ \\
\hline$S A * S A$ & 1 & $0.86^{* *}$ & $1.5587 \mathrm{E}-04^{\mathrm{ns}}$ & $5.5441 \mathrm{E}-03^{*}$ & 1.4020E-03** \\
\hline $\mathrm{ECW} \mathrm{WCW}^{*}$ & 1 & $0.18^{\text {ns }}$ & $3.8900 \mathrm{E}-04^{\mathrm{ns}}$ & $1.0096 \mathrm{E}-04^{\mathrm{ns}}$ & $4.2900 \mathrm{E}-06^{\mathrm{ns}}$ \\
\hline$S A^{*} E C W$ & 1 & $0.0001^{\mathrm{ns}}$ & $6.1480 \mathrm{E}-05^{\mathrm{ns}}$ & 4.4778E-03* & $5.0866 \mathrm{E}-04^{*}$ \\
\hline Residue & 24 & 0.05 & 1.2385E-04 & $9.0433 \mathrm{E}-04$ & 1.0469E-04 \\
\hline CV (\%) & & 23.5 & 20.3 & 28.91 & 30.00 \\
\hline
\end{tabular}
salicylic acid doses and the irrigation waters salinity.

$\mathrm{SV}=$ sources of variation; DoF $=$ degrees of freedom; ${ }^{\text {ns }},{ }^{* *}$ and ${ }^{*}=$ not significant, significant at 1 and $5 \%$ by $\mathrm{F}$ test, respectively. 
values (0.029) were obtained at the $0.69 \mathrm{mM} \mathrm{L}^{-1}$ dose and at 0.5 $\mathrm{dS} \mathrm{m}^{-1}$ salinity (Figure $1 \mathrm{~B}$ ). This behavior indicates the SA action in the cell division process, enabling a greater plant growth. SA promotes cellular protection under stress conditions, thus favoring the integrity of the DNA and RNA membranes and acting on the signaling against stress conditions, as with the case of osmotic adjustment and control of stomatal opening, allowing the plant to hold its vital processes (Feitosa et al., 2016).

The effect of exogenous SA application on the plant growth was observed by other authors, such as Fayez \& Bazaid (2014), who found that applying $50 \mu \mathrm{M}$ of SA attenuated the effect of salt stress and increased the growth of barley plants (Hordeum vulgare L.). Nazar et al. (2015) verified that the $0.5 \mathrm{mM} \mathrm{L}^{-1}$ dose of SA mitigated the effect of salt stress, stimulating photosynthesis, growth and biomass production in mustard plants (Brassica juncea L.). Sultan \& Mohamed (2016) promoted an increased growth of cucumber (Cuccumis sativus L.) by treating its seeds with 0.07 and $0.18 \mathrm{mM} \mathrm{L}^{-1}$ of AS. Silva et al. (2018) found that applying $1.0 \mathrm{mM} \mathrm{L}^{-1}$ of $\mathrm{SA}$ favored the growth of basil (Ocimum basilicum L.) seedlings.

As for the absolute and relative growths, the data from plant height and stem diameter were reduced as a function of the increasing salinity of the irrigation water, with the values fitting to the decreasing linear model (Figure 2). The relative and absolute growth rates, for plant height, also followed the largest increments in plants subjected to a lower ECW 0.5 $\left.\mathrm{dS} \mathrm{m}^{-1}\right)$, succeeded by severe reductions with the increasing salinity, reaching decreases up to 52 and $21 \%$, respectively (Figure 2A and 2B). Damage caused by salt stress on the cell turgor pressure reduces the water content in the tissues, thus resulting in the decline of both cell expansion and the growth of tomato - Lycopersicum esculentum L. (Freire et al., 2010).

The effect of the salicylic acid doses on the absolute growth rate of height demonstrated results that best fit to the quadratic model, with a maximum increment of 1.05 in the 0.9 $\mathrm{mM} \mathrm{L}^{-1}$ dose of SA (Figure $2 \mathrm{C}$ ). The acid acts by regulating the cell cycle and secondary plant metabolism, as well as energy expenditure in the catalyst pathways and in the assimilation rates of the resulting compounds, accumulating them mainly in the plant shoot, making a greater resistance to abiotic stress conditions possible and favoring the growth (Napoleão et al., 2017).

Regarding the fluorescence indexes of chlorophyll ' $a$ ', Table 3 reveals that there was no significant effect for the interaction between the factors and neither for the salicylic acid doses. On the other hand, the irrigation water salinity promoted an effect on maximum and variable fluorescence, the quantum yield of photosystem II and the ratio between variable and initial fluorescence.

The variable and maximum fluorescences were similar, with their values fitting to the decreasing linear effect as the ECW increased, with the highest means in the $0.5 \mathrm{dS} \mathrm{m}^{-1}$ salt level, with 649.64 and 790.41 quantum electrons ${ }^{-1}$, respectively (Figure $3 \mathrm{~A}$ and $3 \mathrm{~B}$ ). The increasing $\mathrm{ECw}$ promoted severe reductions, reaching up to $61 \%$ and $50 \%$ when comparing the
A.

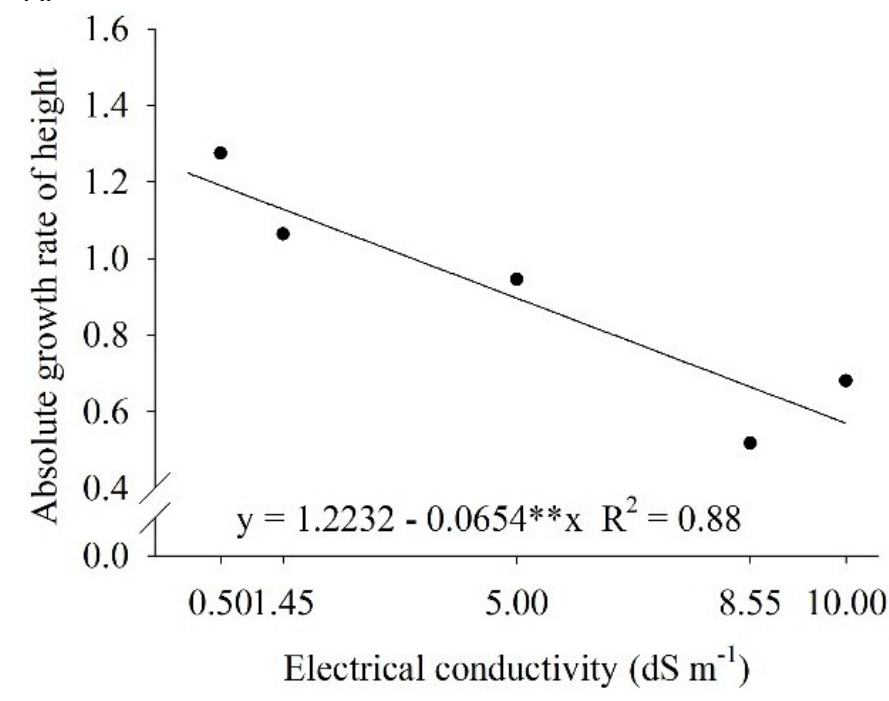

B.

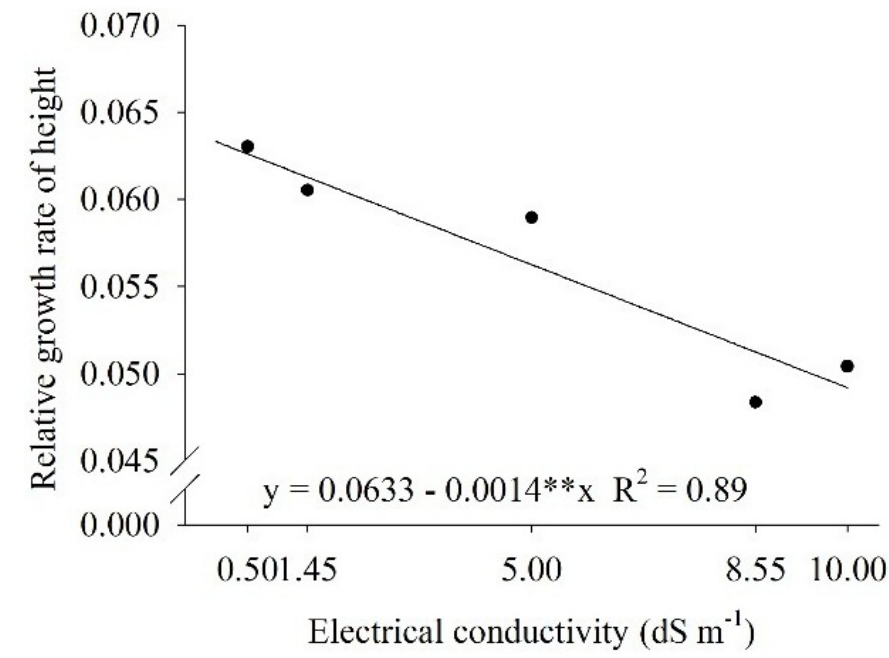

C.

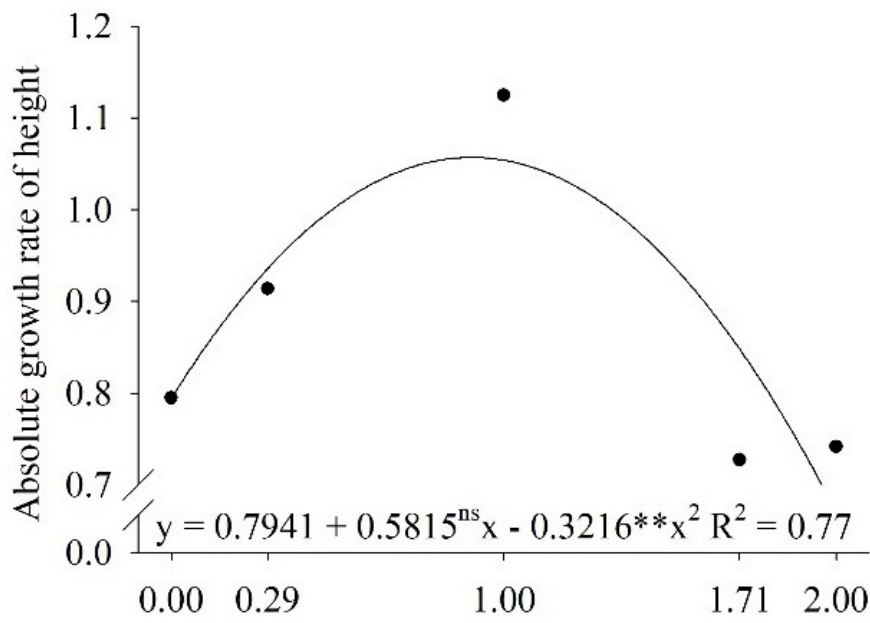

Salicylic acid (mM)

Figure 2. Absolute $(A)$ and relative $(B)$ growth rates for height of Mesosphaerum suaveolens (L.) Kuntze plants subjected to irrigation water salinity and absolute growth rate for plant height $(C)$ in function of salicylic acid doses.

salinity results of the lowest with the highest $\left(10 \mathrm{dS} \mathrm{m}^{-1}\right)$. This effect demonstrates that the high salt content causes severe 
Table 3. Summary of the analysis of variance for the initial $\left(F_{0}\right)$, maximum $\left(F_{m}\right)$ and variable $\left(F_{v}\right)$ fluorescence indexes, quantum yield of photosystem II $\left(\mathrm{F}_{\mathrm{v}} / \mathrm{F}_{\mathrm{m}}\right)$ and the ratio between the variable and initial fluorescence $\left(\mathrm{F}_{\mathrm{v}} / \mathrm{F}_{0}\right)$ of Mesosphaerum suaveolens (L.) Kuntze plants subjected to salicylic acid doses and irrigation water salinity.

\begin{tabular}{ccccccc}
\hline SV & DoF & $F_{0}$ & $F_{m}$ & $F_{v}$ & $F_{v} / F_{m}$ & $F_{v} / F_{0}$ \\
\hline Block & 3 & $5,778.72^{* *}$ & $71,164.003^{* *}$ & $39,237.34^{*}$ & $0.006^{\text {ns }}$ & $2.14^{\text {ns }}$ \\
AS & 1 & $13.15^{\text {ns }}$ & $6,002.80^{\text {ns }}$ & $6,577.93^{\text {ns }}$ & $0.0001^{\text {ns }}$ & $0.74^{\text {ns }}$ \\
ECW & 1 & $751.47^{\text {ns }}$ & $787,481.07^{* *}$ & $739,579.83^{* *}$ & $0.136^{* *}$ & $32.97^{* *}$ \\
AS*AS & 1 & $96.76^{\text {ns }}$ & $732.82^{\text {ns }}$ & $297.006^{\text {ns }}$ & $0.003^{\text {ns }}$ & $0.39^{\text {ns }}$ \\
ECW*ECW & 1 & $1,330.92^{\text {ns }}$ & $22,397.57^{\text {ns }}$ & $12,808.89^{\text {ns }}$ & $0.005^{\text {ns }}$ & $0.06^{\text {ns }}$ \\
AS*EW & 1 & $1,083.51^{\text {ns }}$ & $1,329.54^{\text {ns }}$ & $4,813.52^{\text {ns }}$ & $0.001^{\text {ns }}$ & $2.30^{\text {ns }}$ \\
Residue & 24 & 842.20 & $14,412.94$ & $12,355.07$ & 0.006 & 1.48 \\
CV (\%) & & 20.4 & 19.6 & 23.7 & 10.3 & 35.3 \\
\hline
\end{tabular}

$\mathrm{SV}=$ sources of variation; DoF $=$ degrees of freedom; ${ }^{\text {ns }},{ }^{* *}$ and ${ }^{*}=$ not significant, significant at 1 and $5 \%$ by $\mathrm{F}$ test, respectively.

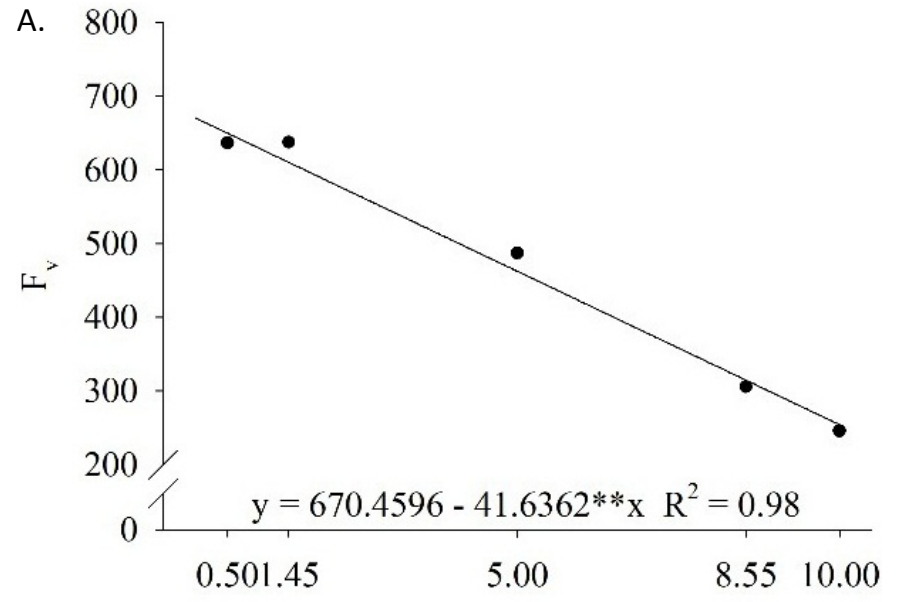

Electrical conductivity $\left(\mathrm{dS} \mathrm{m} \mathrm{m}^{-1}\right)$

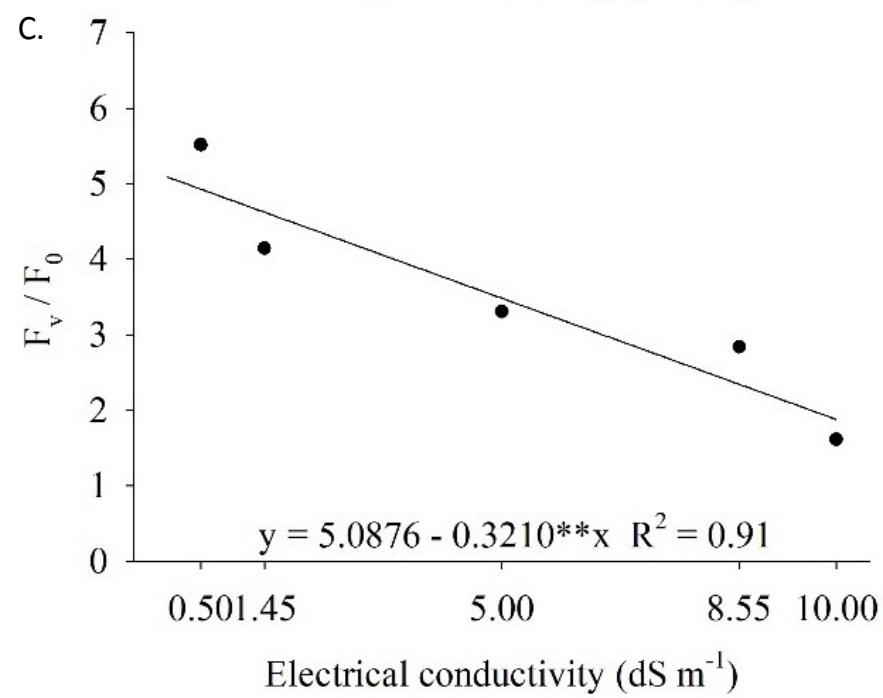

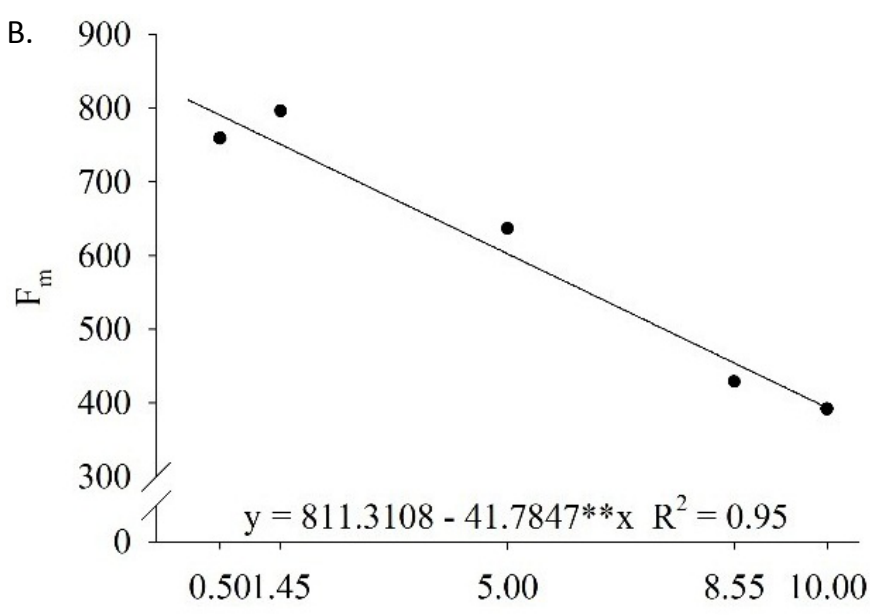

Electrical conductivity $\left(\mathrm{dS} \mathrm{m}^{-1}\right)$

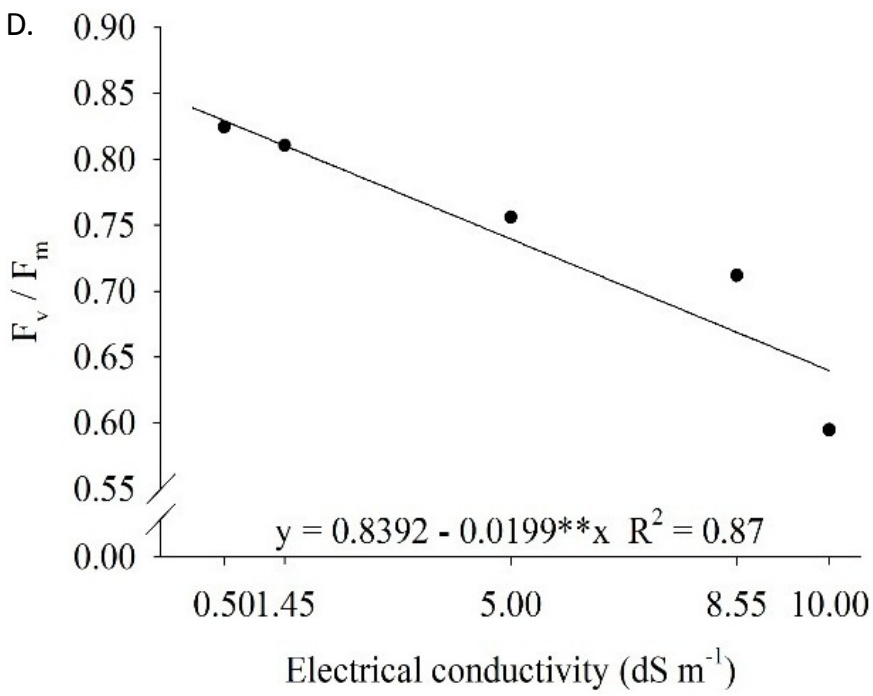

Figure 3. Variable fluorescence $-F_{v}(A)$, maximum fluorescence $-F_{m}(B)$, ratio between maximum and initial fluorescence - $F_{v} /$ $F_{0}(C)$ and quantum yield of photosystem II - $F_{v} / F_{m}(D)$ in Mesosphaerum suaveolens (L.) Kuntze plants subjected to different irrigation water salinities.

damage to the photosynthetic apparatus, corroborating to the $\mathrm{CO}_{2}$ assimilation rate response. These results are indicative that salinity affects the photochemical efficiency, reducing the exchange of electrons among the photosystems and reducing the photochemical activity of the leaves (Lima et al., 2019), thus, plants promote the slowing down of the photosynthetic process as a mechanism for mitigating the salt stress toxic effects (Silva et al., 2014).
In a likely manner, the variables $F_{v}$ and $F_{m}$, behaved as the ratio between maximum and initial fluorescence $\left(F_{v} / F_{0}\right)$ did,

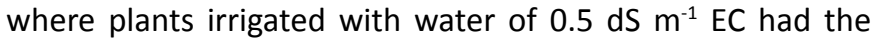
highest values (4.94 quantum electrons ${ }^{-1}$ ) followed by high decreases with the increasing ECw, obtaining a reduction of $62 \%$ in the salinity of $10 \mathrm{dS} \mathrm{m}^{-1}$ (Figure $3 \mathrm{C}$ ). This decrease due to the increasing ECW indicates that the salt stress promotes great damages to the photosynthetic apparatus and the 
efficiency of $\mathrm{CO}_{2}$ carboxylation. This, associated with the negative effect promoted by the salts excess to chlorophyll and on the synthesis of ATP and NADPH, result in low yield and photosynthetic efficiency (Dias et al., 2018).

In a similar fashion, the quantum yield of photosystem II $\left(\mathrm{F}_{v} / \mathrm{F}_{\mathrm{m}}\right)$ had results that fitted to the decreasing linear model, with losses that reached $23 \%$ when comparing the values of plants subjected to lower and higher ECW, emphasizing the damage caused by salt stress(Figure 3D). The reduction in the quantum yield of photosystem II is indicative of damage to the photosynthetic apparatus, where the salinity can inhibit the breakdown of the water molecules needed for the chemical stage of the process, acting directly on photosystem II (Oliveira et al., 2018).

\section{Conclusions}

The seeds treatment with salicylic acid attenuates the damaging effect of irrigation water salinity on the growth of Mesosphaerum suaveolens (L.) Kuntze plants;

The absolute and relative growth rates for the stem diameter are stimulated by the salicylic acid doses of 1.99 and $0.69 \mathrm{mM} \mathrm{L}^{-1}$;

The increased electrical conductivity of irrigation water compromises the growth rates and fluorescence levels of chlorophyll ' $a$ ' in M. suaveolens plants.

\section{Acknowledgements}

The Coordination for the Improvement of Higher Education Personnel (CAPES), for granting scholarships for the graduate students participating in this study.

\section{Literature Cited}

Alves, E. S.; Lima, D. F.; Barreto, J. A. S.; Santos, D. P.; Santos, M. A. L. Determinação do coeficiente de cultivo para a cultura do rabanete através de lisimetria de drenagem. Irriga, v. 22, n. 1, p. 194-203, 2017. https://doi.org/10.15809/irriga.2017v22n1p194-203.

Arruda, M. V. M.; Oliveira, F. F. M.; Sampaio, M. V.; Fernandes, M. D. S. S.; Dias, N. S.; Albuquerque, C. C.; Fernandes, C. S. Influence of nutrition and water stress in Hyptis suaveolens. Industrial Crops and Products, v. 125, n. 1, p. 511-519, 2018. https://doi. org/10.1016/j.indcrop.2018.09.040.

Benincasa, M. M. P. Análise de crescimento de plantas, noções básicas. 2.ed. Jaboticabal: FUNEP, 2003. 41p.

Bezerra, I. L.; Nobre, R. G.; Gheyi, H. R.; Lima, G. S.; Barbosa, J. L. Physiological indices and growth of 'Paluma' guava under saline water irrigation and nitrogen fertigation. Revista Caatinga, v. 31, n. 4, p. 808816, 2018. http://dx.doi.org/10.1590/1983-21252018v31n402rc.

Cody, R. An introduction to SAS University Edition. Cary: SAS Institute, 2015. 339p.

Dias, A. S.; Lima, G. S.; Sá, F. V. S.; Gheyi, H. R.; Soares, L. A. A.; Fernandes, P. D. Gas exchanges and photochemical efficiency of West Indian cherry cultivated with saline water and potassium fertilization. Revista Brasileira de Engenharia Agrícola e Ambiental, v. 22, n. 9, p. 628-633, 2018. https://doi.org/10.1590/1807-1929/agriambi. v22n9p628-633.
Empresa Brasileira de Pesquisa Agropecuária - Embrapa. Sistema brasileiro de classificação de solos. 5.ed. Brasília: Embrapa, 2018. 353p. http:// ainfo.cnptia.embrapa.br/digital/bitstream/item/199517/1/SiBCS2018-ISBN-9788570358004.pdf. 29 Mar. 2019.

Fayez, K. A.; Bazaid, S. A. Improving drought and salinity tolerance in barley by application of salicylic acid and potassium nitrate. Journal of the Saudi Society of Agricultural Sciences, v. 13, n. 1, p. 45-55, 2014. https://doi.org/10.1016/j.jssas.2013.01.001.

Feitosa, S. S.; Albuquerque, M. B.; Oliveira, A. P.; Pereira, W. E.; Brito Neto, J. F. Fisiologia do Sesamum indicum $L$. sob estresse hídrico e aplicação de ácido salicílico. Irriga, v. 21, n. 4, p. 711-723, 2016. https://doi.org/10.15809/irriga.2016v21n4p711-723.

Figueirêdo, F. R. S. D. N.; Bitu Primo, A. J.; Monteiro, A. B.; Tintino, S. R.; Delmondes, G. A.; Sales, V. S.; Rodrigues, C. K. S.; Felipe, C. F. B.; Coutinho, H. D. M.; Kerntopf, M. R. Avaliação da atividade moduladora e citotóxica do óleo essencial das folhas de Hyptis martiusii Benth. Revista Ciencias de la Salud, v. 16, n. 1, 49-58, 2018. https://doi. org/10.12804/revistas.urosario.edu.co/revsalud/a.6489.

Freire, A. L. O.; Saraira, V. P.; Miranda, J. R. P.; Bruno, G. B. Crescimento, acúmulo de íons e produção de tomateiro irrigado com água salina. Semina: Ciências Agrárias, v. 31, n.4, suplemento 1 p. 1133-1144, 2010. https://doi.org/10.5433/1679$0359.2010 v 31 n 4$ Sup1p1133.

Hernández-Ruiz, J.; Arnao, M. B. Relationship of melatonin and salicylic acid in biotic/abiotic plant stress responses. Agronomy, v. 8, n. 4, p. 33-49, 2018. https://doi.org/10.3390/agronomy8040033.

Kalaji, H. M.; Jajoo, A.; Oukarroum, A.; Brestic, M.; Zivcak, M.; Samborska, I. A.; Cetner, M. D.; Lukasik, I.; Goltsev, V.; Ladle, R. J. Chlorophyll $a$ fluorescence as a tool to monitor physiological status of plants under abiotic stress conditions. Acta Physiologiae Plantarum, v. 38, n. 4, p. 102, 2016. https://doi.org/10.1007/ s11738-016-2113-y.

Lima, G. S.; Dias, A. S.; Soares, L. A. A.; Gheyi, H. R.; Nobre, R. G.; Silva. A. A. R. Eficiência fotoquímica, partição de fotoassimilados e produção do algodoeiro sob estresse salino e adubação nitrogenada. Revista de Ciências Agrárias, v. 42, n. 1, p. 214-225, 2019. https://doi.org/10.19084/RCA18123.

Mateus, N. B.; Barbin, D.; Conagin, A. Viabilidade de uso do delineamento composto central. Acta Scientiarum, v. 23, n. 6, p. 1537-1546, 2001. https://doi.org/10.4025/actascitechnol. v23i0.2795.

Napoleão, T. A.; Soares, G.; Vital, C. E.; Bastos, C.; Castro, R.; Loureiro, M. E.; Giordano, A. Methyl jasmonate and salicylic acid are able to modify cell wall but only salicylic acid alters biomass digestibility in the model grass Brachypodium distachyon. Plant Sience, v. 263, p. 46-54, 2017. https://doi.org/10.1016/j.plantsci.2017.06.014.

Nazar, R.; Umar, S.; Kham, N. A. Exogenous salicylic acid improves photosynthesis and growth through increase in ascorbateglutathione metabolismo and $\mathrm{S}$ assimilation in mustard under salt stress. Plant Signaling \& Behavior, v. 10, n. 3, e1003751, 2015. https://doi.org/10.1080/15592324.2014.1003751.

Oliveira, W. J.; Souza, E. R.; Santos, H. R. B.; Silva, E. F. F.; Duarte, H. H. F.; Melo, D. V. M. Fluorescência da clorofila como indicador de estresse salino em feijão caupi. Revista Brasileira de Agricultura Irrigada, v. 12, n. 3, p. 2592-2603, 2018. https://doi.org/10.7127/ rbai.v12n300700. 
Sharma, M.; Gupta, S. K.; Majumder, B.; Maurya, V. K.; Deeba, F.; Alam, A.; Pandey, V. Salicylic acid mediated growth, physiological and proteomic responses in two wheat varieties under drought stress. Journal of Proteomics, v. 163, p. 28-51, 2017. https://doi. org/10.1016/j.jprot.2017.05.011.

Silva, A. O.; Klar, A. E.; Silva, E. F. F.; Tanaka, A. A.; Junior, J. F. S. Relações hídricas em cultivares de beterraba em diferentes níveis de salinidade do solo. Revista Brasileira de Engenharia Agrícola e Ambiental, v. 17, n. 11, p. 1143-1151, 2013. https:// doi.org/10.1590/S1415-43662013001100003.

Silva, L. A.; Brito, M. E. B.; Sá, F. V. S.; Moreira, R. C. L.; Soares Filho, W. S.; Fernandes, P. D. Mecanismos fisiológicos em híbridos de citros sob estresse salino em cultivo hidropônico. Revista Brasileira de Engenharia Agrícola e Ambiental, v. 18, suplemento, p.s1-s7, 2014. https://doi.org/10.1590/1807-1929/agriambi.v18nsupps1-s7.
Silva, T. I.; Nóbrega, J. S.; Figueiredo, F. R. A.; Sousa, L. V.; Ribeiro, J. E. S.; Bruno, R. L. A.; Dias, T. J.; Albuquerque, M. B. Ocimum basilicum $\mathrm{L}$. seeds quality as submitted to saline stress and salicylic acid. Journal of Agricultural Science, v. 10, n. 5, p. 159166, 2018. https://doi.org/10.5539 / jas.v10n5p159.

Sultan, S. M. E.; Mohamed, M. F. Growth and yield of cucumber plants derived from seeds pretreated with salicylic acid. Journal Boil Chemistry Enviromental Sciences, v. 11, n. 1, p. 541-561, 2016. https://www.academia.edu/25115419/Growth_and_ Yield_of_Cucumber_Plants_Derived_from_Seeds_Pretreated_ with_Salicylic_Acid. 18. Mar. 2019.

Taiz, L.; Zeiger, E.; Møller, I. M.; Murphy, A. Fisiologia e Desenvolvimento Vegetal. 6.ed. Porto Alegre: Artmed, 2017. $858 \mathrm{p}$. 